Discussion Paper No. 06-038

\title{
Afterlife - Who Takes Heart for Restart?
}

Georg Metzger

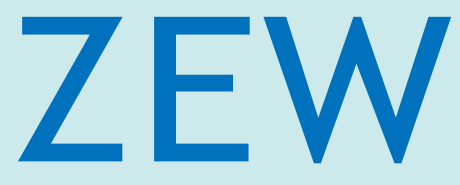

Zentrum für Europäische Wirtschaftsforschung $\mathrm{GmbH}$

Centre for European

Economic Research 


\title{
Discussion Paper No. 06-038 \\ Afterlife - Who Takes Heart for Restart?
}

\author{
Georg Metzger
}

Download this ZEW Discussion Paper from our ftp server:

ftp://ftp.zew.de/pub/zew-docs/dp/dp06038.pdf

Die Discussion Papers dienen einer möglichst schnellen Verbreitung von neueren Forschungsarbeiten des ZEW. Die Beiträge liegen in alleiniger Verantwortung der Autoren und stellen nicht notwendigerweise die Meinung des ZEW dar.

Discussion Papers are intended to make results of ZEW research promptly available to other economists in order to encourage discussion and suggestions for revisions. The authors are solely responsible for the contents which do not necessarily represent the opinion of the ZEW. 


\section{Non-technical summary}

The topic of entrepreneurship research slightly changes from the firm-view to the individual level, i.e. the focus shifts increasingly to the entrepreneur behind the firm as the object of investigation. In the course of this, it became apparent that a large section of the entrepreneurial activity is attributable to habitual entrepreneurs and therefore to individuals establishing more than once. These serial- or portfolioentrepreneurs have entrepreneurial experience that helps them to perform better on average than inexperienced entrepreneurs. However, entrepreneurial experience often goes to waste since starting anew is rarely the first option if one has already failed with a firm.

The approach in this paper is to identify the key factors characterizing entrepreneurs who failed with a business (i.e. went bankrupt) but started anew after the set-back (so called 'restarters'). Two main hypotheses are tested: firstly, is restart probability increased by the length of entrepreneurial experience? Secondly, does the financial affliction of failure prevail in the case of a restart? Moreover, a set of explanatory variables comprising the personal, entrepreneurial, and regional level is applied.

The analysis is based on the ZEW Foundation Panel. The panel relies on information supplied by Creditreform, the largest German credit rating agency. Getting provided with the data on a half-yearly cycle, the ZEW was able to build up this panel encompassing foundations since 1990. For the purpose of investigating entrepreneurs rather than firms this dataset is used for the very first time and is therefore new.

The results found in this paper clearly indicate that there are key factors characterizing entrepreneurs who fail but then start anew. With respect to the formulated main hypotheses the results are ambiguous. No evidence is obtainable in favor of a more likely restart with increasing time previously spent in entrepreneurship. By contrast, the negative debt dependence of restart is confirmed. Moreover, there are further findings: for instance, men are more likely to restart than women, as are entrepreneurs with university degree; the entrepreneur's age affects the restart probability negatively. Testing for industry affiliation reveals significant evidence that restart likelihood is promoted by several industries. 


\title{
Afterlife - Who Takes Heart for Restart?
}

\author{
Georg Metzger \\ Center for European Economic Research (ZEW), Mannheim, \\ P.O. Box 103443 D-68034 Mannheim, metzger@zew.de
}

June 2006

\begin{abstract}
The performance of young and newly founded firms depends largely to the human capital of the firm owner. The entrepreneur is therefore one of the main success factors for the firm. Yet entrepreneurs differ considerably in their background and characteristics. Particularly, founders' individual entrepreneurial experience is a property that might be crucial for firm development, though it is part of the firm's human capital, too. Business failures, namely bankruptcies, may trigger the transition from being a novice entrepreneur to becoming an entrepreneur who is entrepreneurially experienced. About 3 percent of novice entrepreneurs who file for bankruptcy reestablish afterwards. On average, slightly more than 15 months will elapse until such 'fallen' entrepreneurs venture out anew. They differ from entrepreneurs not willing or able to take a second chance in several respects.
\end{abstract}

Keywords: $\quad$ Bankruptcy; Business Failure; Restart; Second Chance; JEL Classification: J23; M13; G33;

\section{Acknowledgements}

The author would like to thank Dirk Czarnitzki, Michael Fritsch, Georg Licht, Bettina Peters, and Ralf Wilke for their help and valuable comments, and Creditreform for providing their database. 


\section{Introduction}

The approach in this paper is to identify the key factors characterizing entrepreneurs who failed with a business but started anew after the set-back (so called 'restarters'). Such a specification "allows us to make better predictions [...] about the likely behavior, responses, and success of the entrepreneur" (Woo et al., 1991, p. 93). The business failures covered by the cases we consider are all bankruptcies, that is, the state of insolvency is a legal finding. Voluntary firm exits are often due to economic reasons, too, and, therefore, may also count among business failures. The restriction to bankruptcies, thus, is a limitation of the analysis but is nevertheless reasonable. In 1999 a new insolvency law was introduced in Germany. This reform took place in order to standardize the rules valid in West- and East-Germany and to correct several limitations of the previous statutes which were more than 120 years old and which had thus become inappropriate. The new rules facilitate that going bankrupt does not necessarily mean the end of an entrepreneurial career. Due to a 30-year liability for private debts this was previously the custom. Failed freelancers, craftsmen and sole proprietors are now able to establish a new business unmortgaged by debts. The discharge procedure enables debt relief after a minimum of six years 'on probation' (in German: 'Wohlverhaltensperiode') even if not the whole sum or only a minimum debt quota has been paid back within this period (Trendelenburg, 2000). ${ }^{1}$ That is, the "debtor is under the obligation to work or at least to take pains to get a job in order to hand over a great part of what is earned to its creditors. A number of further co-operation duties exist in this period which are sanctioned by the denial of discharge in case of misbehaving" (Paulus, forthcoming). Having the prospect of debt relief after filing for insolvency was an adjustment towards a more debtor friendly system. This specific reform issue was based on the assumption that the abandonment of entrepreneurial careers after bankruptcy was mainly caused by the burden of debt. In reality, however, we cannot be certain of this. As yet, there has been no investigation into what determines a restart. The research question of "who takes heart for restart" is therefore important to work this point out. Was the 'remaining debt' assumption founded or is the restart decision based on other, perhaps more important, factors. It is reasonable in theory that, apart from indebtedness, there are several determinants which lastingly affect the restart decision. In this regard the human-capital-theory plays a role as well as the principal/agent theory and the evolutionary theory. Last but not least, a country's entre- 
preneurial culture is also an essential influencing factor for (ex-)entrepreneurs. The intention behind facilitating restarts might have resulted from studies considering habitual entrepreneurship. Some of them claim that previous entrepreneurial experience affects firm success positively. That is, experienced entrepreneurs shine with both higher growth and survival of their firms. Additionally, indications exist that the very experience of business failure fosters the employment and turnover growth of subsequent firms and, therefore, restarts.

The remainder of the paper is structured as follows. Section 1 contains a brief discussion of the theoretical foundation. In Section 2 the literature drawn up to that topic previously is reviewed, while Section 3 introduces the applied data and methodology. Descriptive statistics and the estimation results are commented in Section 4 before Section 5 closes the article with some summarizing conclusions.

\section{Theoretical Background and Hypotheses}

Entrepreneurs who suffered a business failure have to weigh up the individual, social, and economic factors of their restart decision, maybe arriving at the conclusion that they should leave the entrepreneurial career path (Dyer, 1994). The exit decision might be suggested by understanding their failure as a signal that they would be better off abandoning all entrepreneurial purposes. This view is supported by the Darwinian evolutionary theory advocating a 'survival-of-the-fittest'- respectively 'natural selection'-thesis: firms disappear since the market rejects businesses or even business ideas, showing that the managers' entrepreneurial competence was not good enough to succeed in competition (Penrose, 1952). Therefore, many exentrepreneurs returned to employee status after having had to close their firms (Ronstadt, 1986). Unfortunately, from the applied sample it is only apparent whether a restart took place or not. Therefore, it is not obvious if there was an attempt to start anew which was foiled by something or someone. That is, it cannot be proved if ex-entrepreneurs abandoned their entrepreneurial career voluntarily due to the loss of confidence in their entrepreneurial capabilities. However, very often it is not clear if the firm failure was due to entrepreneurial incompetence or due to external effects which cannot be influenced by the concerned entrepreneurs. The reality of imperfect markets allows for several such causes, for example, the appearance of strong competitors dominating the market, plagiarism or behavior modification of state regulation. Imperfections, thus, limit the survival-of-the-fittest-doctrine.

\footnotetext{
1 If the insolvency court admits the debtor's plea for discharge (in German: 'Restschuldbefreiung'), the period of good behavior begins retroactively with the bankruptcy proceeding's opening.
} 
Ronstadt, 1982, notes that a lot entrepreneurs were at first engaged in several (failed) businesses before they got involved in a successful one. This approach is comprehensible under the 'human capital'-theory: it suggests that investments in skills through formal educational attainment, training-on-the-job or professional experience increase one's performance (Mincer, 1974; Becker, 1985). Entrepreneurial experience includes training-on-the-job as well as professional experience. These enhance the entrepreneur's human capital. And, the longer the experience took to acquire, the higher the investment is. Since the prospect of increased performance should heighten one's motivation to restart, the first and main hypothesis of this paper can be put forward as follows:

\section{H1: Restart probability increases in conjunction with human-} capital enhancing education or training and, therefore, also with the time previously spent in entrepreneurship.

Leaving the entrepreneurial career path after business failure is similar to depreciating specific human capital. The question is why a large number of entrepreneurs do depreciate their knowledge and reject restart. An answer might be derived by the 'principal/agent'-theory. (Jensen and Meckling, 1976) The restart decision is not exclusively a decision by the failed entrepreneurs who are agents in this context. Several principals, for example loan officers, are involved in the process, too. Asymmetric information disadvantages these principals, that is, they cannot be sure about the failed entrepreneurs' real intentions. Thus, they need to be convinced that the restart is promising and well thought-out. Theory suggests doing that by measures of signaling. That is, one has to set the principals a good example, maybe by getting additional financiers (e.g. family and friends) on board. Usually, financial backers screen the credit applicants' backgrounds to shed light upon their intentions. In the special case of restarters - to their regret - the two very striking factors which immediately attract the principals' attention are the applicant's previous business failure, superficially indicating their incompetence (see above), as well as the debt resulting from the failure. These items make it more difficult for the entrepreneur to convince the principals of the opposite, and in the case of credit granting it makes the credit rating worse, which in turn makes borrowing dearer. Especially when the new capital requirements directive for credit institutions and investment firms (Basel II) is in policy execution one might get conscious of the new insolvency law's discharge rules' importance. Nevertheless, it is economically rational to put hard facts such as a former business failure and the resulting debt from it into a 
rating very quickly. Thus, the second hypothesis can be put forward in the following way:

\section{H2: Restart probability decreases reciprocally to the level of debt}

(resulting from business failure).

Nevertheless, the weight with which both business failure and debt are introduced into the rating is not definite. Each credit institute or credit rating agency varies in dealing with the evaluation. Weighting differences, however, result not only from the banking system, but also from a country's entrepreneurial culture, that is, how it deals with its entrepreneurs. In the U.S., for example, self-employment ${ }^{2}$ is appreciated as a signal of willingness to bear risks. Failures are all part of it being tolerated by the system and by society. German society, for example, behaves contrarily to that: low risk-taking attitudes prevail. Failures are not as tolerated as in AngloSaxon systems so that some even talk about stigmatization of failure. Therefore, to fail with a business is likely to weigh more heavily in rating models - the worst result of which would be a refusal of credit.

\section{Related Literature}

One of the other analyses known to follow a similar argumentation was conducted by Wagner, 2003. By seeking determinants of "Who takes the second chance?" in Germany he investigated in which respect formerly failed entrepreneurs trying to restart differ from those leaving their entrepreneurial career path. He relies on survey data, namely on information from the Global Entrepreneurship Monitor (GEM), which is an international survey among the population of the participating countries. As all survey data results, this poll's findings rest, of course, on the assumption that the answers provided by the interviewees are reliable. In Wagner's work the 'self-assessment bias' concerns the issue of whether they had in the past 'closed or given up' a firm. If they answer in the affirmative there is, unfortunately, no way to check whether the former firm went bankrupt or was closed due to financial distress. Therefore, it cannot be definitely clarified if the firm closure actually was a firm failure in the sense defined herein. Nevertheless, Wagner found that especially younger individuals and the higher educated alike take the second chance. They are, in addition, comparatively less risk averse and have rather more contact with other start-up entrepreneurs.

2 The term 'self-employment experience' is often used synonymously with 'entrepreneurial experience'. It is beyond doubt that this is not precisely the same, for example in the case of a freelancer. 
Besides Wagner's analysis there is no other research that explicitly tackles the determinants of restarters. Several studies (for example Westhead and Wright, 1998a;1998b, Westhead and Wright, 1999, Westhead et al., 2005) take serialentrepreneurs into account. These serial-entrepreneurs show, however, similarities to the restarters in Wagner's definition, since they have also 'closed or given up' a firm previously for sure. But, Westhead and Wright consider serial-entrepreneurs' determinants compared to novice entrepreneurs. This is in contrast to Wagner whose comparison group consists of ex-novice entrepreneurs, have already turned their backs on entrepreneurship. Westhead and Wright, 1998a;1998b, apply data from a pencil-based survey among independent new and small businesses in Great Britain performed in late 1990 and early 1991. With regard to the family background they found that novices are more often from underprivileged classes of society; the share of entrepreneurs whose parents were unskilled employees was more than twice as much in case of novice entrepreneurs. The working life is more turbulent in case of serial entrepreneurs since they have a higher number of organizations they worked for prior to the job in the surveyed firm. Respectively to the reasons leading to start-up several significant deviations occur, even though the levels differ by a range of 7 to 12 percentage-points only. Serial-entrepreneurs agree with the statements 'follow role models' and 'need for personal development' to a higher extent than novices. Contrarily, the latter are more prone to agree to causes like 'need for independence' and 'welfare considerations'. In the case of serialentrepreneurs, the start-up's sourcing is more likely based on personal savings and on capital of family and friends.

Westhead et al., 2005, base their results on a representative sample of private firms in Scotland. They found that serial entrepreneurs are more innovative than novice entrepreneurs. A higher share of the former group affiliates give an affirmative answer to each of the questions of whether they introduced both product and process innovations. This is maybe due to the brainstorming process with respect to the business idea. Compared to novices, serial entrepreneurs would rather describe the business idea as issue of an 'accidental process' than as a planed result.

\section{Data and Methodology}

\section{Database}

For the analysis of the entrepreneurs' restart decision and its determinants, the ZEW Foundation Panel (see Almus et al., 2000, for details) is employed. The panel relies on information provided by Creditreform, the largest German credit rating agency. 
The data contains not only general information about newly founded firms in Germany but also details about individuals whose entrepreneurial activities have been observed longitudinally. Firm-specific business failure information along with data about the firm owners allow the identification of those persons who reestablish after business failures. The ZEW Foundation Panel currently contains information on more than 4 million German firms and their founders established after 1989. The probability that a bankrupt firm is recorded in the data is nearly one hundred percent. Therewith, the ZEW Foundation Panel provides a representative database for restart analysis in Germany.

\section{Definitions}

As explained above, a business failure is defined as bankruptcy. "It is widely perceived that all exits from self-employment are failures, but is this necessarily the case?" (Taylor, 1999, p. 144) Actually, the definition of what event is considered a business failure is not easily construed. That firm closure and business failure are not necessarily identical is shown by the comments of Everett and Watson, 1998. They gathered five basic categories of closure: discontinuance of ownership, discontinuance of the business, bankruptcy, disposal with losses to prevent further losses and inability to 'make a go of it'. All of these include a different subset of closed firms - of course with possible overlaps. Nevertheless, only the last three account for business failure. Thus, recent entrepreneurs who 'closed or gave up' a firm in the past, as Wagner defined restarters, may have had completely different reasons for having done so as compared to the ones who suffered a business failure. For instance, "organizations [can] differ in their thresholds of performance, and exit or survival is determined by whether economic performance falls below or stays above that firm-specific thresholds" (Gimeno et al., 1997, p. 751). In consequence, such (ex-)entrepreneurs come to the decision to start anew under different preconditions than restarters do. On the other hand one could argue that smart entrepreneurs who act with foresight exit the market before they are forced to file for bankruptcy. However, due do to data restrictions it is not possible to control for these cases.

Besides compiling the closure categories, Everett and Watson also especially emphasize that in the former literature "generally, the definition of failure used has, to a large extent, depended on the nature of the data available" (Everett and Watson, 1998, p. 374). Consequently, since the ZEW Foundation Panel contains exact status information with regard to running bankruptcy proceedings, 'bankruptcy' is used as the failure event. With this definition it seems to be clear if and when a business 
failure occurs. Yet the opening of a bankruptcy proceeding may be dismissed for different reasons. Hence, it is necessary to delimit the case of bankruptcy rather strictly. Bankruptcy, therefore, applies only in the case of regular opening of the bankruptcy proceeding, that is, without rejection of the opening request for insufficiency of assets.

The accurate definition of the bankruptcy event is important. Kranzusch and Günterberg, 2001, argue that dishonest debtors might sap the firm's capital prior to filing for bankruptcy. This causes the opening request's rejection due to the insufficiency of assets. Owing to this a closer investigation of the firm's business activities, as would be the case in the regularly opened bankruptcy proceeding, is avoided. ${ }^{3}$ In consequence, the delinquent debtors would be able to reestablish free of debt. In this way the debt absconders may in some cases even pass through repeated cycles of business formation and purposive bankruptcy. To avoid considering these individuals as legitimate restart entrepreneurs, the definition of the bankruptcy event must be, indeed, restrictive. Unfortunately, owing to the fact that the opening requests of many firms in the panel which filed for bankruptcy were rejected, most observations are dropped from further analysis.

In addition, the chronology of events revolving around business formation and bankruptcy is considered for case selection as well. In many of the recorded observations with a multi-firm entrepreneurial biography, firm-closure and restart overlap with one another, i.e., the restart's founding date is earlier than the reported opening date of the bankruptcy proceedings. In these cases it is not clearly attributable whether they account for a restart or not. One is disposed not to consider such cases as restarts as the chronological order indicates so-called portfolio entrepreneurship where firms are established parallel to each other. Adequate categorization hinges on the closeness of events in founding the second firm and opening the first firm's bankruptcy proceeding. In absence of justifiable assumptions concerning this categorization issue, it is more practicable to strictly rely on the chronology of events, and thus not to count these cases of parallel business formation as restarts.

Therefore, in summary, a restart entrepreneur is defined as someone who suffers bankruptcy as a novice - regardless if she/he was a member of the founding team or just joined an existing firm - and launches a new firm (restart) after the opening of

\footnotetext{
3 The opening request's rejection due to the insufficiency of assets is indeed sufficient condition for an administrative investigation by the insolvency practitioner. Nonetheless, the inquiry is much less indepth relative to an inquiry following a regular opening since in the case of rejection the insolvency practitioner's scrutiny will be thwarted by the threat of not getting his money's worth.
} 
the bankruptcy proceeding. ${ }^{4}$ In the following, these entrepreneurs will be called restarters. In the awareness that entrepreneurs joining an existing firm differ from entrepreneurs really founding a firm and working in it from the start, I control for this effect by applying an appropriate dichotomous variable. ${ }^{5}$ The related articles mentioned above give some clarification on several characteristics of serial entrepreneurs. However, it is impossible to draw any conclusions regarding the determinants of previously failed entrepreneurs on the basis of this empirical evidence. Applying the restart definition, a business failure by a subsequent restarter is observed in the panel for the first time in 1992. Due to associated data restrictions, observations where the first bankruptcy was recorded prior to the year 1995 were dropped. Altogether, more than five-hundred restart cases are available from the database according to the above criteria. These are included in the analysis.

\section{Variables}

The characterization of restarters is based on three types of data: it relies (1) on the individual's personal information, (2) on information related to their bankrupt firms, and (3) on data describing the region of the firms' location. The values of all the variables characterize the state at the time when the first failure symptom in terms of the legal bankruptcy proceeding occurs. ${ }^{6}$ Individual data is introduced since it reflects three issues affecting the restart decision: human capital endowment conditioning career alternatives, family status accounting for both social and pecuniary commitments to family and, finally, general risk-taking attitude. With this type of data, thus, it is possible to test the human-capital-related hypothesis. Firm information can be used to control for the role played by the extent of the debt burden as well for industry specific behavior. Hence, firm data is applied for testing of the second hypothesis. Last but not least, regional conditions are considered relevant. Founding conditions have long-lasting effects on a firm's growth and survival (Geroski et al., 2003). Therefore, impacts on the entrepreneur cannot be ruled out and indeed are likely. Detailed information on the variables (measurement, empirical evidence, expected influence and its rationale) is given in Table A 1 (see Appendix).

4 Only insolvency of the first establishment in the person's entrepreneurial biography applies. Furthermore, the biography is considered by the time of the first successful firm-foundation (i.e. not ending in bankruptcy).

5 To identify the relevant entrepreneur(s) among all participants involved, we took account of participation in both equity and management. Only individuals who have shares in equity and work in the management simultaneously are considered as relevant.

6 The first failure symptom is mostly, but not necessarily, filing for insolvency. In other cases it may rather be its affirmation or the proceedings' opening (in the cases the filing hasn't been registered). 
The applied set of variables is expandable of course. Effects arising, for example, from the entrepreneur's social capital, from the specificity of her/his skills or from a good match between her/his human capital and the applied business model on the restart probability are conceivable. But, due to the lack of data, one has to make do with the specification as it stands.

The data preparation results in a gross sample of about 33 thousand failed entrepreneurs. Unfortunately, the complete set of variables does not exist for all of the identified entrepreneurs, so observations had to be deleted on a case-by-case basis. ${ }^{7}$ In order to discard only a minimum number of observations the approach advocated by Cohen and Cohen, 1983, is applied to variables with a large number of missing values. In this approach, separate dummy variables were generated taking on the value one, if the relevant variable shows missing values; in return, the missing values were coded with zero afterwards. By this approach most observations could be maintained, henceforth adding up to nearly 29 thousand individuals. ${ }^{8}$

\section{Econometric Specification}

To identify the determinants for entrepreneurial restart a binomial Probit estimation approach is used. I apply three binomial Probit models, varying the variables and/or observations introduced. Model A is the base model which uses all observations. The Models B and C were estimated to consider Western and Eastern Germany separately. In all three regressions the decision to start anew after a business failure is considered to be endogenous and modelled as a binary response. That is, the criterion variable takes on the value one in the case of entrepreneurial restarts after filing for bankruptcy and zero otherwise.

\section{Empirical Results}

\section{Descriptive Statistics}

Some descriptive statistics summarizing the investigated groups are provided in Table 1. Restarters account for a little less than 3 percent of the entrepreneurs who filed for bankruptcy. That is substantially lower than the share that Wagner, 2003, observed in his survey. In his sample of failed entrepreneurs a restarter-share of about 8 percent results. The explanation for this difference draws on the respective

7 The lack of values is not systematic, that is, the omission of observations does not bias the sample.

8 Jones, 1996, argues that this approach results in biased estimators due to overestimating the residual variance which "can weaken the power of a $t$ test that compares two of the nonmissing groups." But, this problem seems to be negligible compared to the information loss of complete-case analysis. 
definitions of failure: While Wagner asks about firms that have been closed or given up which includes voluntary exits, the analysis presented here exclusively employs recorded bankruptcy-events. The number of voluntary exits is roughly similar to the number of bankruptcies (Prantl, 2003). Thus, there is a high potential that respondents assess themselves as restarters in survey data, although they discontinued voluntarily. Since an entrepreneur who dropped out voluntarily is more likely to restart than a failed entrepreneur - which is rather due to divergence of opportunity than of willingness - the measured share is increased. More than 90 percent of the restarters are male, an average which is 12 percent above that for the group of non-restarters. Additionally, they are more than two and a half years younger than the non-restarters who average 45 years of age, are more academically educated, are rarely married, and raise children slightly less often.

Table 1: Descriptive Statistics

\begin{tabular}{|c|c|c|c|c|c|c|c|c|c|c|}
\hline \multirow[t]{2}{*}{ Variables } & \multicolumn{3}{|c|}{$\begin{array}{c}\text { All Failed } \\
\text { Entrepreneurs }\end{array}$} & \multicolumn{3}{|c|}{$\begin{array}{c}\text { Non- } \\
\text { Restarters }\end{array}$} & \multicolumn{3}{|c|}{ Restarters } & \multirow{2}{*}{$\begin{array}{l}\text { Significance } \\
\text { Level }^{(1)}\end{array}$} \\
\hline & Mean & SD & $\begin{array}{c}\text { \# of } \\
\text { Obs. }^{(2)} \\
\end{array}$ & Mean & $\mathrm{SD}$ & $\begin{array}{c}\text { \# of } \\
\text { Obs. }^{(2)} \\
\end{array}$ & Mean & $\mathrm{SD}$ & $\begin{array}{c}\text { \# of } \\
\text { Obs. }^{(2)} \\
\end{array}$ & \\
\hline$\%$ Restarter & 0.03 & & & 0.00 & & & 1.00 & & & \\
\hline Gender ( $\%$ male $)$ & 0.80 & 0.40 & & 0.79 & 0.41 & & 0.91 & 0.29 & & $* * *$ \\
\hline Age & 44.76 & & 26,819 & 44.84 & & 26,063 & 42.22 & & 756 & $* * *$ \\
\hline \multicolumn{11}{|l|}{ Education } \\
\hline$\%$ Academics & 0.29 & & 26,582 & 0.29 & & 25,826 & 0.37 & & 756 & $* * *$ \\
\hline \% Master Craftsmen & 0.16 & & 17,836 & 0.16 & & 17,258 & 0.12 & & 578 & $* * *$ \\
\hline \multicolumn{11}{|l|}{ Family Status } \\
\hline$\%$ Have Children & 0.22 & & 17,836 & 0.22 & & 17,258 & 0.19 & & 578 & $*$ \\
\hline$\%$ Married & 0.88 & & 16,588 & 0.88 & & 16,116 & 0.84 & & 472 & $* *$ \\
\hline Firm Size (\# of employees) & 17.63 & 43.76 & 22,827 & 17.48 & 43.60 & 22,127 & 22.44 & 48.48 & 700 & $* * *$ \\
\hline Legal Form (\% limited liability) & 0.67 & & & 0.66 & & & 0.92 & & & $* * *$ \\
\hline Corporate Real Property ( $\%$ yes) & 0.23 & & & 0.24 & & & 0.14 & & & $* * *$ \\
\hline Founder Member (\% yes) & 0.29 & & & 0.29 & & & 0.33 & & & $* * *$ \\
\hline Team (\% multi-owner firms) & 0.32 & & & 0.32 & & & 0.44 & & & $* * *$ \\
\hline Time Spent in Previous Firm & 3.69 & 3.32 & & 3.71 & 3.34 & & 3.22 & 2.30 & & $* * *$ \\
\hline Rate of Unemployment in the Region & 12.44 & 5.18 & & 12.47 & 5.19 & & 11.47 & 4.87 & & $* * *$ \\
\hline Foundation Intensity in the Region & 45.67 & 11.94 & & 45.61 & 11.92 & & 47.62 & 12.65 & & $* * *$ \\
\hline Business Failure Intensity in the Region & 7.63 & 2.92 & & 7.65 & 2.92 & & 7.05 & 2.73 & & $* * *$ \\
\hline Region Type (\% metropolitan districts) & 0.46 & & & 0.46 & & & 0.59 & & & $* * *$ \\
\hline Number of Observations & & & 28,965 & & & 28,193 & & & 772 & \\
\hline
\end{tabular}

When restarters went bankrupt for the first time they employed an average of 22 employees, five more than other failed firms. Also, compared to non-restarters, they ran their business from their own firm premises just under half as frequently, at the point of bankruptcy. Status as a founder member is slightly more prevalent in the restarter group, and about 12 percentage points more restarters were part of multiowner firms, possibly related to the higher share of limited liability enterprises at 92 
percent. Their average length of participation in the failure firm is a half year shorter than that of non-restarters. Restarters and non-restarters set up their failed firms in regions which differ in all regional indicators considerably. Regions in which restarters were located show decreased unemployment rate, increased foundation intensity, lower business failure intensity and are up to 10 percentage-points more often metropolitan areas.

Another interesting structural fact is the distribution of the entrepreneurship interruption length, i.e., the duration that restarters remain entrepreneurially inactive after the business failure. As Figure 1 shows it is a right skewed distribution. On average, 15 months elapse before a failed entrepreneur realizes her/his restart. In 50 percent of cases, overall, a restarter does not take the second chance until 7 months have passed since the bankruptcy proceeding's opening. In terms of peak frequencies, restarters appear not to waste a lot of time and start their new ventures directly after the bankruptcy, that is, within the first 4 months. Such a closure/restartbehavior may be related to several reasons, but first of all it seems to be strategically induced, for example in terms of dealing with mounting debt. In the face of conceivably unaffordable liabilities, one may seek to overcome through advancing plans for new ventures. By the time bankruptcy hits, one is, thus, prepared for an early restart. But by no means all restarts are strategically motivated; an early restart is also possible due to the commitment to a business idea, and if the first attempt fails the second comes directly to the fore.

Figure 1: Distribution of the Entrepreneurship Interruption Length

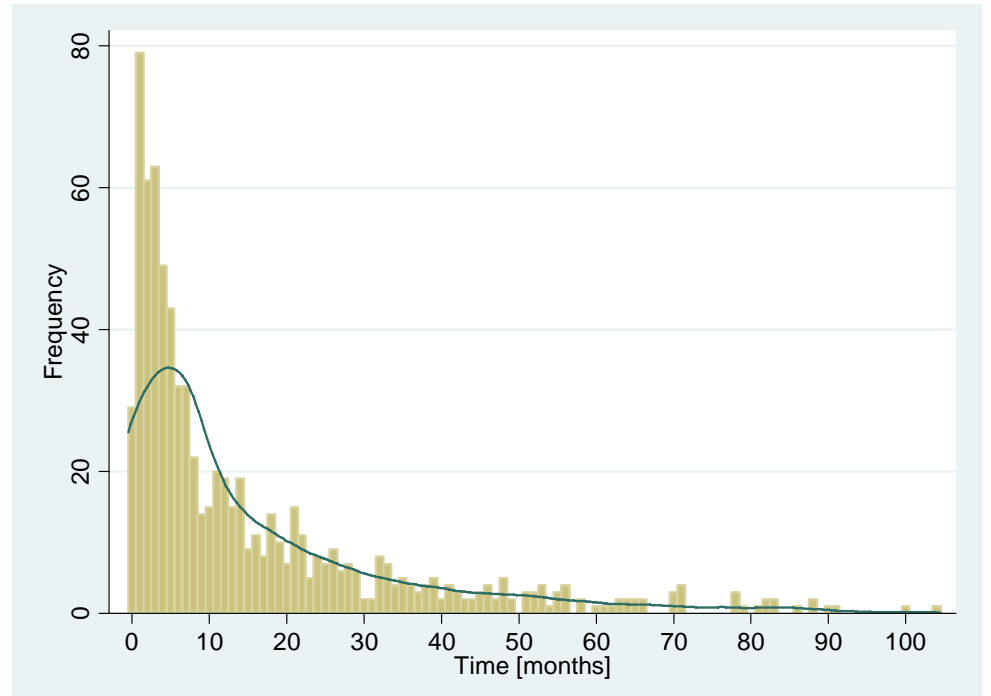

Note: The outlined curve traces the distribution's kernel density function. The number of cases is 772 .

Source: ZEW Foundation Panel. 
Nevertheless, the large number of restarts in the first 4 months after failure indeed suggests that these restarts are calculated in relation to the avoidance of warranties or obligations. The consideration of the sample's industry distribution in Table 2 may help to underpin that most restarters, however, haven't been sailing (too) close to the wind.

The structure reveals that 50 percent of all bankruptcies occur in construction and trade services - an equal share in each - and another fifth in consumer services. The remainder is shared by manufacturing, company related services, and other sectors at similar percentages. The industry distribution for non-restarters differs mainly in two respects: the share of manufacturing is distinctly larger and the share of consumer services clearly smaller than in case of all bankruptcies. That might be owing to the transition counting individuals instead of firm entities, which can however not be verified here. Restarters differ in three items from the industry structure of non-restarters and, what is more, in virtually every industry compared to all bankruptcies. The relative number of failures in consumer services and trade services are lower than in the case of non-restarters, in contrast to a much higher share in company related services. As regards the hypothesis of warranty or obligation avoidance this distribution is contradictory: significantly larger shares of restarters in industries with on average high obligations or long-term warranties - such as manufacturing and construction - should rather be a point in favor of the above supposition, but not just slightly higher shares. There is also the fact that merely 37 to 56 percent of the entrepreneurs continue in the same industry in which they were engaged with their $1^{\text {st }}$ firms when they establish again (within industry restarts). Supposing that the first market entry is caused to a large extent by entrepreneurs' skills, it is plausible, to assume that those who just want to evade commitments are more likely to restart within the same industry than the others. But, at around 50 percent withinindustry-restart shares are not sufficient to support such a conclusion, particularly since it can be maintained that entrepreneurs will again want to build on their skills, with or without criminal intent. On the other hand the business-cycle-theory gives a rationale for changing sectors for a restart. If there are bad economic conditions in an industry the number of sector-specific bankruptcies will increase. An entrepreneur who wants to restart then would do better either to wait a while before restarting in the same industry, or change his/her sector affiliation to start anew. This business-cycle-hypothesis is partly supported by the descriptive statistics. The share of restarters who have experience within their industry increases with the time that has passed since bankruptcy: it rises from 42 percent in the case of restart in the first 12 
months, up to 58 percent if up to 6 years have passed since bankruptcy. Afterwards the share varies unsystematically.

Table 2: Industry Structure

\begin{tabular}{|c|c|c|c|c|c|c|c|}
\hline \multirow[b]{2}{*}{ Industry } & \multirow[b]{2}{*}{$\begin{array}{c}\text { Bankruptcies } \\
(1995-2004)\end{array}$} & \multirow[b]{2}{*}{$\begin{array}{l}\text { Non-Restarters } \\
\text { (initial failure) }\end{array}$} & \multirow[b]{2}{*}{ (1) } & \multicolumn{4}{|c|}{ Restarters } \\
\hline & & & & $\begin{array}{c}1^{\text {st }} \text { Firm } \\
\text { (initial failure) }\end{array}$ & (2) & $\begin{array}{l}2^{\text {nd }} \text { Firm } \\
\text { (restart) }\end{array}$ & $\begin{array}{l}\text { Within } \\
\text { Industry } \\
\text { Restarts }\end{array}$ \\
\hline Manufacturing & $11.6 \%$ & $16,2 \%$ & $* *$ & $18.8 \%$ & $* * *$ & $14.0 \%$ & $41.4 \%$ \\
\hline Including: Technology-Intensive Manufacturing & $2.0 \%$ & $4,1 \%$ & & $3.5 \%$ & & $3.4 \%$ & $22.2 \%$ \\
\hline Company Related Services & $12.1 \%$ & $11,9 \%$ & $* * *$ & $20.9 \%$ & & $22.7 \%$ & $46.6 \%$ \\
\hline Including: Technology-Related Services & $4.8 \%$ & $5,2 \%$ & $* * *$ & $11.5 \%$ & & $10.7 \%$ & $30.3 \%$ \\
\hline Non-Technical Consulting Services & $3.2 \%$ & $2,7 \%$ & $* * *$ & $5.4 \%$ & $* *$ & $8.1 \%$ & $40.5 \%$ \\
\hline Consumer Services & $18.6 \%$ & $13,4 \%$ & $* * *$ & $9.1 \%$ & $* * *$ & $13.6 \%$ & $37.1 \%$ \\
\hline Construction & $24.7 \%$ & $26,7 \%$ & & $25.5 \%$ & $* * *$ & $20.3 \%$ & $55.8 \%$ \\
\hline Trade Services & $24.7 \%$ & $24,0 \%$ & $* *$ & $20.6 \%$ & & $20.9 \%$ & $51.6 \%$ \\
\hline Other Sectors & $8.1 \%$ & $7,7 \%$ & $* * *$ & $5.2 \%$ & $* * *$ & $8.6 \%$ & $45.0 \%$ \\
\hline All Industries & $100 \%$ & $100 \%$ & & $100 \%$ & & $100 \%$ & $48.1 \%$ \\
\hline Number of Observations & 302,672 & 28,193 & & 772 & & $700^{(3)}$ & \\
\hline
\end{tabular}

From the event of restarts emerges an industry structure different from the one known among initial establishments that fail. The resulting distribution is relatively symmetric: three industries (company related services, trade services and construction) account for roughly 20 percent each, whereas both manufacturing and consumer services level off more or less at 14 percent. Overall, compared to the initial industry composition four significant differences occur. While consumer services and residual sectors exhibit raised proportions, the shares of manufacturing and construction each decrease.

\section{Estimation Results}

Table 3 reports the estimation results of the binomial Probit estimates for determinants of restarters. In the second column, the resulting coefficients of Model A, which is the base model, are depicted. The thoughts on the first hypothesis related with the human-capital-theory, that 'restart probability increases in conjunction 
Table 3: Coefficients on Binomial Probit Estimates for Determinants of Restarters

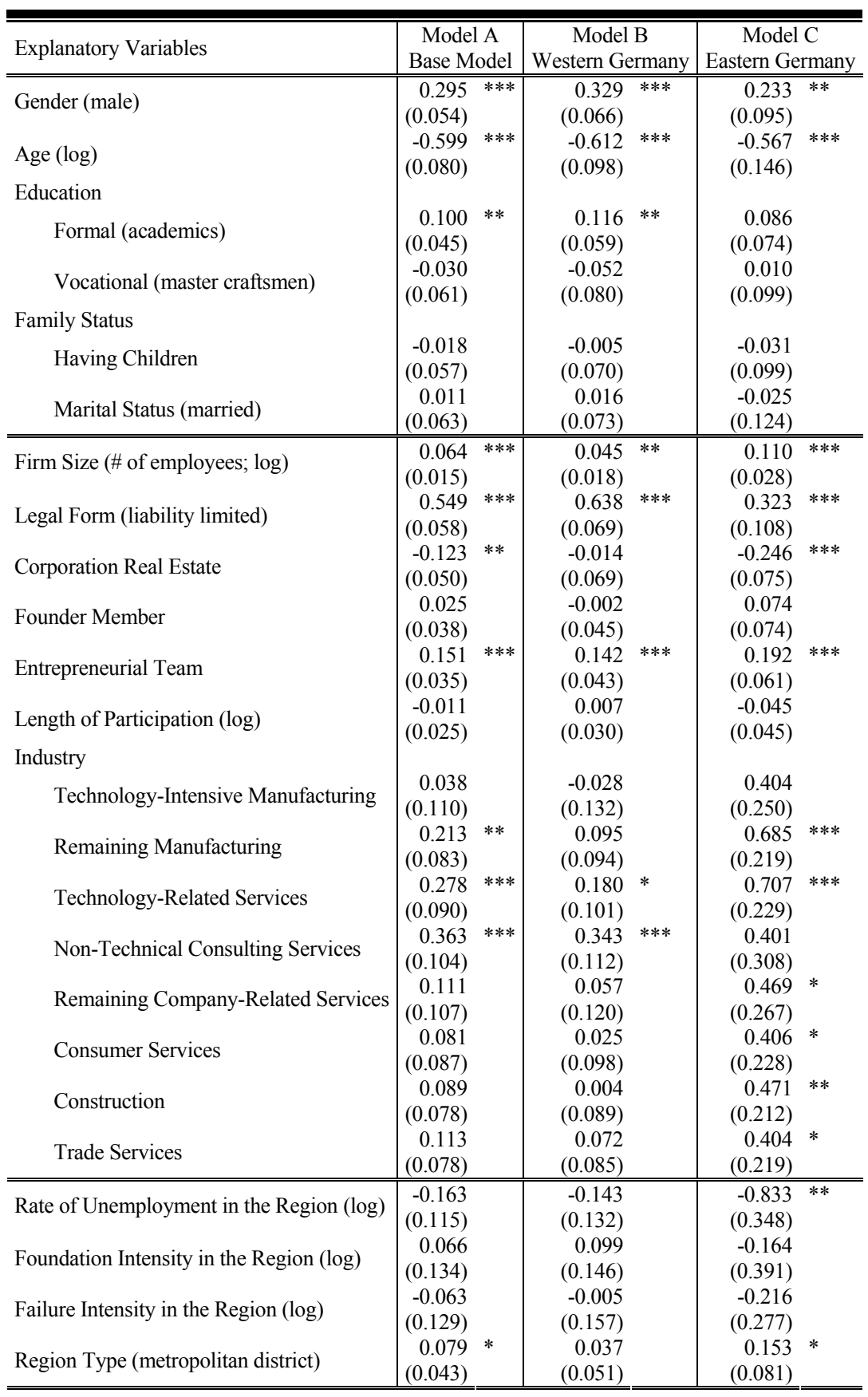


Table 3: Coefficients on Binomial Probit Estimates for Determinants of Restarters, (continued)

\begin{tabular}{|c|c|c|c|}
\hline Explanatory Variables & $\begin{array}{c}\text { Model A } \\
\text { Base Model } \\
\end{array}$ & \begin{tabular}{|c|} 
Model B \\
Western Germany \\
\end{tabular} & $\begin{array}{c}\text { Model C } \\
\text { Eastern Germany } \\
\end{array}$ \\
\hline \multicolumn{4}{|l|}{ Missing Value Measures } \\
\hline Gender is Missing & $\begin{array}{rl}-0.314 & * * * \\
(0.109) & \end{array}$ & $\begin{array}{l}-0.186 \\
(0.132)\end{array}$ & $\begin{array}{rl}-0.600 & * * * \\
(0.208) & \end{array}$ \\
\hline Age is Missing & $\begin{array}{l}-2.703 * * * \\
(0.313)\end{array}$ & $\begin{array}{l}-2.771^{* * *} \\
(0.377)\end{array}$ & $\begin{array}{l}-2.771^{* * *} \\
(0.588)\end{array}$ \\
\hline Education is Missing & $\begin{array}{l}-0.100 * * \\
(0.045)\end{array}$ & $\begin{array}{l}-0.080 \\
(0.052)\end{array}$ & $\begin{array}{l}-0.159 * \\
(0.092)\end{array}$ \\
\hline Having Children is Missing & $\begin{array}{r}-0.035 \\
(0.041)\end{array}$ & $\begin{array}{r}-0.017 \\
(0.048)\end{array}$ & $\begin{array}{l}-0.095 \\
(0.081)\end{array}$ \\
\hline Marital Status is Missing & $\begin{array}{l}-0.179)^{* * *} \\
(0.063)\end{array}$ & $\begin{array}{l}-0.136 * \\
(0.075)\end{array}$ & $\begin{array}{l}-0.291 * * \\
(0.122)\end{array}$ \\
\hline Firm Size is Missing & $\begin{array}{r}-0.035 \\
(0.062)\end{array}$ & $\begin{array}{r}-0.022 \\
(0.071)\end{array}$ & $\begin{array}{r}-0.085 \\
(0.135)\end{array}$ \\
\hline Constant & $\begin{array}{r}-0.290 \\
(0.625)\end{array}$ & $\begin{array}{l}-0.451 \\
(0.708)\end{array}$ & $\begin{array}{r}2.855 \\
(1.946)\end{array}$ \\
\hline Number of Observations & 28,965 & 18,033 & 10,932 \\
\hline $\begin{array}{l}\text { LR-Test } \chi^{2} \text { on Joint Significance of } \\
\text { the Industry Measures } \\
\text { the Region-Describing Variables } \\
\text { the Federal States Dummies (not reported) } \\
\text { the Failure Year Dummies (not reported) }\end{array}$ & \begin{tabular}{rl|}
25.68 & $* * *$ \\
6.41 & \\
48.44 & $* * *$ \\
7.39 & \\
\end{tabular} & $\begin{array}{r}16.56 * * \\
3.19 \\
5.22 \\
12.15\end{array}$ & $\begin{array}{rl}20.79 & * * * \\
9.87 & * * \\
19.97 & * * * \\
10.75 & \\
\end{array}$ \\
\hline $\begin{array}{l}\text { LR Chi }^{2} \\
\text { Pseudo-R }\end{array}$ & $\begin{array}{c}750.64 \\
0.105\end{array}$ & $\begin{array}{c}459.94 \\
0.097\end{array}$ & $\begin{array}{c}332.90 \\
0.140\end{array}$ \\
\hline McKelvey and Zavoina's $\mathrm{R}^{2}$ & 0.212 & 0.199 & 0.266 \\
\hline
\end{tabular}

with the time spent in entrepreneurship previously' cannot be confirmed. There is no significant effect resulting from the entrepreneurial experience's length. Interpreting its coefficient sign nevertheless, a negative effect from the participation length is to be ascertained. But where does it come from? Independent of her/his human-capital a first work entrepreneur is usually very enthusiastic with respect to her/his business idea or even to the self-employment status at all. Especially if the business fails rapidly this enthusiasm lasts, and might result in an advanced willingness, and therefore realization, to establish anew. Although the competition intensity as a certain determinant of the participation length differs between industries the average length in entrepreneurship is very similar across them. Thus, the effect of the time spent in entrepreneurship is independent from industry affiliation. Although formal education increases human capital, too, its state is negligible regarding the human capital thesis. In most cases the formal education already exists before the entrepreneurial career begins. Therewith, it does not reinforce human capital during the first entrepreneurial phase and thus cannot be considered as a 'specific investment' (provided that the formal education was not entrepreneurship-related, a possibility which is not observable in the data). However, a significantly positive effect comes from academic education. Failed entrepreneurs who have a university degree, thus, are more likely to restart than others. Nevertheless, a university degree does not control for the availability of specialized knowledge (for example man- 
agement or business skills) which might be helpful for handling business failure and which may have been gained from attending university. Therefore, this measure maps not just academic education itself but rather other skills and values imparted by an academic environment that foster the willingness to restart. On all accounts, despite a decreasing share of academics in serial entrepreneurs overall (Westhead and Wright, 1998a), a university degree plays an important role in terms of reestablishing post-bankruptcy. Master craftsmen show no significantly differing behavior. 'Master craftsman' is a German-specific craftsmen title. To attain the master craftsmen diploma, candidates must first complete an apprenticeship and then gain some working experience in the respective sector afterwards. Given these preconditions, the diploma can absolutely be seen as measure for specific technical skills. Its insignificance is surprising, since it is also a specific investment into entrepreneurship: the crafts sector has been highly regulated, that is, the diploma was a necessary condition for establishing. Hence, this entry barrier should actually increase restart probability, even in conjunction with the human capital thesis.

By contrast more evidence is given in regard to the second hypothesis. Actually, there are several variables which support that 'restart probability decreases reciprocal to the level of debt' resulting from business failure. Firstly, the likelihood of a restart is significantly heightened if the business failure occurred with limited liability. It restricts potential financial affliction by both the limitation of liability and the (at the time of founding irksome) more difficult access to credit at all. Secondly, the assumption that the likelihood of restarting depends on financial factors is strengthened by the negative effect of corporate real estate proprietary, i.e., the firm owns real estate such as developed sites. Financing corporate real property like working or administration premises needs a large stake of capital, to which end lenders often demand private collateral, e.g. guaranties. Thus, even in the case of limited liability legal forms entrepreneurs are nevertheless fully liable. Due to this, real property indicates exceeding (private) debts lowering restart probability by downgrading creditworthiness. The case of team-ruled firms is linked with financial considerations, too. But now, the rationale takes hold from both the pro and the con side. Team-ruling of a firm accounts for limited, or split, financial affliction, as well as the eventuality of excessive debts. Since the estimation indicates a positive effect on the restart probability, the 'pro-side' impact seems to dominate.

The remaining results can be summarized as follows. Failed male entrepreneurs are more likely to restart as compared to their female counterparts. The popular wisdom in research which suggests such gender dependence of entrepreneurship affinity is 
strengthened therewith: men are not only more likely to become self-employed but also restart more often in the case of failure. A heightened restart probability is found for younger persons as the sign of 'age' is negative. This finding holds even if applying a specification including 'age' as quadratic term: then, a more or less linear relationship with negative slope results nevertheless. The effects arising from family commitments are unambiguous. Neither the existence of children ${ }^{9}$ nor the entrepreneur's marital status seems to affect the restart realization. Checking for possible gender dependence on the impact of the family status by interacting 'gender' with the family status dummies also shows no significant effect. Furthermore, failed entrepreneurs are more likely to restart the bigger the former firm was. This may be caused by the scope of tasks and responsibilities rising with firm size. No determining role is played by the experience as a founder member: taking a second chance is independent from it. Industry affiliation considered at the aggregated industry level affects the restart decision significantly. Entrepreneurs who failed in non-technology-intensive manufacturing, technology-related services and nontechnical consulting services show significantly increased restart likelihood. ${ }^{10}$ Regional conditions are of little relevance to restarts. The Model A regression reveals no other significant regional variable except the positive impact of the region typeeven if it is only weakly, i.e. at the $10 \%$-confidence level, significant. Given the high number of observations a 5\%-confidence level should be reached for analytic proof at least. The unreported control variables, namely the federal state and failure year dummies, are of ambiguous influence. While it is relevant for restart in which federal state the failure took place it makes no difference to the restart behavior when the business failure occurs: not only are all of the single failure year dummies are insignificant, but the joint significance of the failure year dummies is also rejected. As expected this indicates that the insolvency reform does is not yet taking effect in the first years after implementation.

The Models B and C distinguish by the firm's origin but include the initial set of variables in other respects. Therefore, Model B fits the restart indicator on data of entrepreneurs settled in Western Germany while Model C applies information on entrepreneurs localized in Eastern Germany. Despite the long time since the German unification took place, such a distinction makes sense as the difference between the economic levels of the two German regions is still quite enormous. The

9 Information about the children's age is not available. Testing for a gender or team foundation dependence of the family state dummies by applying interaction terms of the relevant variables reveals no further significant effects.

${ }^{10}$ A Wald-test cannot reject the null hypotheses that the coefficients are equal. 
two estimations reveal by which region the effects measured in the base Model A are induced. Academic education and non-technical consulting services are the only two variables which are important in Model A but exclusively significant in the regression restricted to Western Germany. In turn, the impact of corporate real estate property and failure in non-technology-intensive manufacturing resulting from the initial estimation are only significant in the East German case. Furthermore, some effects are valid for the East German specification but were not measured in base Model A. These are, firstly, failure in construction and, secondly, the rate of unemployment which affects restart probability negatively as in accordance with our expectation. Referring to the East German specification the effects of failure in non-technology-intensive manufacturing, technology-related services and construction each are very strong. Performing Wald-tests cannot reject the null hypotheses on equality of the coefficients with exception of the case of non-technologyintensive manufacturing compared to construction. The joint effect of the federal states dummies is insignificant in Model B, that is, in the Western states of Germany the location seems to be irrelevant. Additionally, the finding that the year in which the business failure occurred plays no role is confirmed. The joint significance of the failure year dummies is rejected in both regional specifications.

\section{Conclusions and Preview}

In order to tap the potential of firm formation by experienced entrepreneurs, it is useful to reduce restart obstacles. This requires gaining a detailed picture of the potential target group, i.e. taking a closer look at the characteristics of failed entrepreneurs and at (possible) key determinants of restarters. The results found in this paper clearly indicate that there are key factors characterizing entrepreneurs who failed but start anew. Restart probability depends on several factors which differ perhaps not exclusively - on personal, entrepreneurial, and regional levels. Ambiguously are the results with respect to the hypotheses prepared: no evidence is obtainable in favor of the idea that restart is more likely with increasing time previously spent in entrepreneurship. By contrast, the negative debt dependence of restart is confirmed. Therewith, an indication supporting the 'remaining debt'-assumption, which was basically for getting the insolvency law reform off the ground, is found. Moreover, there are further findings which are widely as expected yet, surprisingly, family status ultimately plays no role for the likelihood to restart. Actually one could expect that it does due to financial reasons, for example because the uncertainty of returns from a firm founded does not guarantee the continuous income needed for large household upkeep. However, financial matters seem to be the 
dominant influencing factor affecting restart likelihood even if not in the case of family status. Several of the determinants referring to the firm-level are associated with the financial background: the legal form as an indicator of personal liability, corporate real estate as a measure of indirect private borrowing or team entrepreneurship as a dimension of potential individual affliction. They all point to a strong dependence of the restart decision on financial means. Also quite unexpected is that the rate of unemployment approximating the availability of alternative job opportunities is irrelevant for risking the second chance, at least in West Germany.

The analysis shows, therefore, that this in-depth investigation of previous findings is generally needed. Firstly, applying another database containing administratively valid information yields confirmatory results regarding some effects indicated by survey data analysis. Nevertheless, not all findings are robust enough for generalization and have to be put into perspective. Secondly, employing additive firmrelated variables accommodates unexpected insights in their relevance for decisionmaking, for example the meaningfulness of former team-work or industry affiliation.

However, only 3 percent of failed entrepreneurs make another attempt to establish. This is less than half of the share of self-employed individuals in the working age population. Owing to the insolvency law reform, the time period after 2005 will be a very interesting year for further research on the topic of restarters. In this year the 'probation' period matures for the very first time and, therefore, surely prompts the first discharged restarters under new legislation. ${ }^{11}$ For the additional analysis this might mean a change in the significance of several variables, especially with regard to variables accounting for financial affliction. Furthermore some research is planned in order to analyze the success, i.e. performance and/or survival of restarts.

11 A restart during the years on probation is basically possible, but it bears imponderability: at first, it must be agreed with the creditors and, secondly, the failure of the business results inevitably in the rejection of discharge. 


\section{$6 \quad$ References}

Almus, M., D. Engel and S. Prantl (2000), The „Mannheim Foundation Panels“ of the Centre of European Economic Research, ZEW, Mannheim.

Becker, G.S. (1985), Human Capital, Effort, and the Sexual Division of Labor, Journal of Labor Economics 3 (No. 1), 33-58.

Cohen, J. and P. Cohen, (1983), Applied multiple regression/correlation analysis for the behavioral sciences 2 , Hillsdale.

Dyer, W.G. (1994), Toward a Theory of Entrepreneurial Careers, Entrepreneurship Theory and Practice, 7-21.

Everett, J. and J. Watson (1998), Small Business Failure and External Risk Factors, Small Business Economics 11, 371-390.

Geroski, P.A., J. Mata and P. Portugal (2003), Founding Conditions and the Survival of New Firms, No. 1-03, Lisboa.

Gimeno, J., T.B. Folta, A.C. Cooper and C.Y. Woo (1997), Survival of the Fittest? Entrepreneurial Human Capital and the Persistence of Underperforming Firms, Administrative Science Quarterly 42, 750-783.

Jensen, M.C. and W.H. Meckling (1976), Theory of the Firm: Managerial Behavior, Agency Costs and Ownership Structure, Journal of Financial Economics 3 (No. 4), 305-360.

Jones, M.P. (1996), Indicator and Stratification Methods for Missing Explanatory Variables in Multiple Linear Regression, Journal of the American Statistical Association 91 (433), 222-230.

Kranzusch, P. and B. Günterberg (2001), Erste Auswirkungen der Insolvenzrechtsreform 1999 auf mittelständische Unternehmen, IfM-Materialien No. 150, Bonn.

Mincer, J. (1974), Schooling, Experience, and Earnings, National Bureau of Economic Research, New York.

Penrose, E.T. (1952), Biological Analogies in the Theory of the Firm, The American Economic Review, 804-819. 
Prantl, S. (2003), Bankruptcy and Voluntary Liquidation: Evidence for New Firms in East and West Germany after Unification, ZEW Discussion Paper No. No. 03-72, Mannheim.

Ronstadt, R. (1982), Does Entrepreneurial Career Path Really Matter? Proceedings of Babson College Entrepreneurship Research Conference, Wellesley, Mass: Center for Entrepreneurial Studies, Babson College.

Ronstadt, R. (1986), Exit stage left: Why Entrepreneurs end their entrepreneurial careers before retirement, Journal of Business Venturing 1, 323-338.

Taylor, M.P. (1999), Survival of the fittest? An analysis of self-employment duration in Britain, The Economic Journal 109 (454), C140-C155.

Trendelenburg, H. (2000), Discharge in Germany from an International Point of View, INSOL International Insolvency Review 9, 111-120.

Veall, M.R. and K.F. Zimmermann (1996), Pseudo-R ${ }^{2}$ Measures for some Common Limited Dependent Variable Models, Journal of Economic Surveys 10 (3), 241-259.

Wagner, J. (2003), Taking a Second Chance: Entrepreneurial Re-starters in Germany, Applied Economics Quarterly 49 (3), 255-272.

Westhead, P., D. Ucbasaran, M. Wright and M. Binks (2005), Novice, Serial and Portfolio Entrepreneur Behaviour and Contributions, Small Business Economics 25, 109-132.

Westhead, P. and M. Wright (1998a), Novice, Portfolio, and Serial Founders in Rural and Urban Areas, Entrepreneurship Theory and Practice 22 (4), 63100 .

Westhead, P. and M. Wright (1998b), Novice, portfolio, and serial founders: Are they different?, Journal of Business Venturing 13 (3), 173.

Westhead, P. and M. Wright (1999), Contributions of Novice, Portfolio and Serial Founders Located in Rural and Urban Areas, Regional Studies 33 (2), 157 173.

Woo, C.Y., A.C. Cooper and W.C. Dunkelberg (1991), The Development and Interpretation of Entrepreneurial Typologies Journal of Business Venturing 6, 93-114. 
Table A 1: Variables: expectations and descriptions

\begin{tabular}{|c|c|c|c|c|}
\hline & Determinant & $\begin{array}{l}\text { Empirical Evidence } \\
\text { (own expectation) }\end{array}$ & Measurement & Rationale \\
\hline 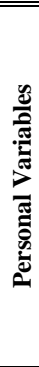 & $\begin{array}{l}\text { Formal } \\
\text { Education } \\
\text { Children } \\
\text { Marriage }\end{array}$ & $\begin{array}{l}+ \\
(-) \\
(-)\end{array}$ & $\begin{array}{l}\text { By means of the } \\
\text { highest achieved } \\
\text { educational attainment. }\end{array}$ & $\begin{array}{l}\text { Females are still not as respected in business as males are. } \\
\text { This ought to hold even more in the case of failure. } \\
\text { The desire for founding one's own firm decreases with age } \\
\text { (MittelstandsMonitor, 2004), it is plausible to assume this for } \\
\text { restarters, too. In consequence, failed younger entrepreneurs } \\
\text { will be more willing to take risks than older ones. } \\
\text { Highly educated individuals who suffer bankruptcy gain } \\
\text { experience which is valuable for other firms raising their } \\
\text { market value. Thus, they may find suitable employment after } \\
\text { business closure rather than test a restart. } \\
\text { Keeping a spouse and family might reduce risk affinity and } \\
\text { should affect restart likelihood negatively. }\end{array}$ \\
\hline 尊 & $\begin{array}{l}\begin{array}{l}\text { Entrepreneu- } \\
\text { rial Team }\end{array} \\
\text { Industry } \\
\text { Failure Year }\end{array}$ & $\begin{array}{c}(-) \\
\text { Relevant }^{(1)}\end{array}$ & $\begin{array}{l}\text { Specified as duration } \\
\text { of firm-attendance } \\
\text { until the initial failure } \\
\text { symptom occurs as } \\
\text { registered in the formal } \\
\text { proceedings. }\end{array}$ & $\begin{array}{l}\text { The scope of tasks and responsibilities is correlated with the } \\
\text { size of a firm and, therefore, the larger an entity is, the more } \\
\text { one can learn. } \\
\text { Beneath the lowering of financial afflictions, legal implica- } \\
\text { tions work in favor of a positive effect of limited liability. } \\
\text { Unlimitedly liable entrepreneurs who suffered insolvency are } \\
\text { recorded in a defaulter register for three years impeding } \\
\text { virtually all access to capital during the scheduled term. } \\
\text { The existence of corporate real estate is a measure of the } \\
\text { borrowing ceiling level and, thus, for exceeding debts. } \\
\text { Deficiencies in general and financial management skills are to } \\
\text { be associated with bankruptcies of younger firms; older firm's } \\
\text { insolvency is linked with changes in the competitive envi- } \\
\text { ronment (Thornhill and Amit, 2003). This relation should } \\
\text { similarly hold for entrepreneur's firm-attendance (instead of } \\
\text { for firm-age only). In the case of shorter firm-attendance } \\
\text { (younger firms), thus, the deficiencies might be compensated } \\
\text { by the learning effects inherent to self-employment experi- } \\
\text { ence and subsequent insolvency heightening probability for } \\
\text { restart. } \\
\text { An entrepreneur might have been more struck by the failure } \\
\text { than an entrepreneur who was not involved in the foundation, } \\
\text { because founder members are more overconfident than other } \\
\text { entrepreneurs (Forbes, 2000). } \\
\text { Team-rule can lower financial afflictions from bankruptcy } \\
\text { due to the sharing of costs, but .on the other hand it also eases } \\
\text { borrowing. The effect on restart probability, thus, is ambigu- } \\
\text { ous. } \\
\text { Industries characterized by high competition markets are } \\
\text { more likely to put restarters off. }\end{array}$ \\
\hline 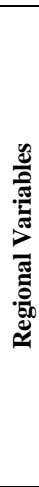 & $\begin{array}{l}\text { Foundation } \\
\text { Intensity } \\
\text { Failure } \\
\text { Intensity }\end{array}$ & Relevant (-) & $\begin{array}{l}\text { \# of firm-foundations } \\
\text { per } 10.000 \text { employable. } \\
\# \text { of bankruptcies per } \\
10.000 \text { employable. } \\
\text { Core cities and districts } \\
\text { with more than } 300 \\
\text { residents per sq. } \\
\text { kilometer. }\end{array}$ & $\begin{array}{l}\text { High unemployment limits entrepreneurs' chances of finding } \\
\text { a job and increases, therefore, the probability of taking the } \\
\text { second chance as an entrepreneur. On the other hand, how- } \\
\text { ever, districts with high unemployment are characterized by } \\
\text { for example reduced purchasing power, or disputable market } \\
\text { shares by necessity founders reducing the prospects for new } \\
\text { firms already from the outset. } \\
\text { In fact, 'foundation intensity' may serve as a measure of the } \\
\text { entrepreneurial climate in a region, and the better the climate } \\
\text { is the more likely it is for other attempts to be made. } \\
\text { Indicates contested or missing/matured markets. } \\
\text { With reference to Wagner (2003) the contact with 'role } \\
\text { models' fosters the realization of restarts, though such per- } \\
\text { sonal contacts are more likely in agglomerations. }\end{array}$ \\
\hline
\end{tabular}

12 The multiple-ventures-creator to single-venture-creator ratio decreases with entrepreneurs' age (Ronstadt, 1986). 